\title{
Revitalisasi Perpustakaan Sekolah Untuk Meningkatkan Minat Baca Siswa
}

\author{
Siti Munawarah ${ }^{1}$ \\ ${ }^{1}$ SDN 54/IX Sungai Gelam, Jambi, Indonesia
}

\begin{tabular}{l} 
Article Info \\
\hline Article history: \\
Received Mei 9, 2020 \\
Revised Mei 17, 2020 \\
Accepted Mei 28, 2020 \\
\hline
\end{tabular}

Keywords:

Minat Baca

Perpustakaan

Revitalisasi

\begin{abstract}
ABSTRAK
Tujuan Penelitian: Penelitian ini bertujuan untuk mengetahui bagaimana revitalisasi perpustkaan sekolah dalam meningkatkan minat baca siswa.

Metodologi: Data penelitian ini diperoleh dengan menggunakan pendekatan kualitatif. Pendekatan kualitatif menggunakan instrumen observasi, wawancara dan dokumentasi. Setelah data didapatkan maka akan di analisis menggunakan teknik analisis Miles and Huberman.

Temuan Utama: Hasil penelitian menunjukkan bahwa revitalisasi perpustakaan sekolah untuk meningkatkan minat baca siswa sudah meningkat dengan baik. Hal ini dibuktikan berdasarkan hasil observasi bahwa dengan adanya revitalisasi, perpustakaan sudah terlihat bagus, sarana dan prasarana sudah cukup memadai, kondisi dan kenyamanan ruangan sudah ditingkatkan. Didukung dengan hasil wawancara yang mana dengan adanya revitalisasi perpustakaan, pihak sekolah membuat kegiatan berkunjung secara rutin ke perpustakaan dengan bimbingan guru, setiap satu hari satu kelas yang telah ditentukan untuk berkunjung ke perpustakaan. Dengan kegiatan yang bernilai positif seperti itu maka siswa akan terbiasa untuk berkunjung ke perpustakaan dan minat baca siswa akan lebih meningkat.
\end{abstract}

Aplikasi dalam Penelitian: Revitalisasi perpustkaan yang ada di sekolah diharapkan mampu meningkatkan minat siswa dalam membaca.

Keterbarauan: Dengan melakukan revitalisasi perpustakaan yang ada disekolah, mampu menumbuhkna minat baca oleh para siswa.

Copyright $@ 2020$ Cahaya Ilmu Cendekia Publisher All rights reserved.

\section{Corresponding Author:}

Siti Munawarah

SDN 54/IX Sungai Gelam, Jambi, Indonesia

Email: sitimunawarah122@gmail.co.id

\section{PENDAHULUAN}

Perpustakaan merupakan hal yang sangat penting di tingkat sekolah dasar karena pada masa itulah siswa dapat dibiasakan kreatif mencari berbagai sumber informasi. Itu artinya perpustakaan merupakan unit kerja yang menghimpun, mengelola dan menyajikan kekayaan untuk kepentingan pendidikan, pelestarian dan informasi untuk mencerdaskan kehidupan bangsa [1]. Keberadaan perpustakaan sekolah tidak sebatas tempat penyimpanan buku paket pelajaran, tetapi justru harus mampu menyajikan alternatif sumber ilmu yang dibutuhkan dan selama ini sulit diakses siswa.

Perpustakaan sekolah sangat diperlukan, terutama untuk membantu proses belajar mengajar disekolah [2]. Selain itu perpustakaan sekolah merupakan tempat memupuk kerjasama antarsiswa dalam berinovasi. Sebagai lembaga pendidikan formal, sekolah menduduki posisi yang sangat penting dan strategis dalam peroses belajar mengajar. Salah satunya dengan mengoptimalkan fungsi perpustakaan. Perpustakaan merupakan suatu unit kerja dari suatu badan atau lembaga tertentu yang mengelola bahan-bahan pustaka, baik berupa buku maupun bukan berupa buku yang diatur secara sistematis menurut aturan tertentu sehingga 
dapat digunakan sebagai sumber informasi oleh setiap pemakainya [3]. Perpustakaan juga tidak sebatas koleksi cetakan, tetapi dapat diperluas media atau multimedianya, seperti dilengkapi dengan audiovisual, digital.

Mengingat begitu pentingnya keberadaan perpustakaan disekolah sebagai salah satu sumber belajar untuk siswa, namun tidak begitu saja keberadaannya dapat berdayaguna tanpa adanya suatu manajemen yang baik dan terprogram. Karena bagaimanapun dan dalam hal apapun manajemen merupakan bagian pokok dalam suatu program atau kegiatan efisiensi dan efektifitas, manajemen perpustakaan disekolah dapat tercapai apabila seluruh sumber daya yang ada mampu dan mau bersinergi baik itu sumber daya manusia, sarana dan prasarana serta dana yang dimiliki [4]. Oleh karena itu perlunya manajemen berupa program revitalisasi perpustakaan yang telah dikembangkan disekolah tersebut.

Revitalisasi perpustakaan merupakan usaha yang dilakukan agar perpustakaan dapat memegang perannya kembali sebagaimana mestinya [5]. Tujuan dari program ini adalah untuk mengembalikan peran perpustakaan sekolah sesuai dengan tujuan dan fungsinya yaitu melalui kegiatan pembaharuan pengelolaan perpustakaan sekolah, sehingga perpustakaan sekolah kembali berperan sebagai jantung sekolah dan dapat meningkatkan minat baca siswa [6]. Menurut peraturan menteri pekerjaan umum No. 18 tahun 2010 tentang pedoman revitalisasi. Revitalisasi adalah upaya untuk meningkatkan nilai melalui pembangunan kembali yang dapat meningkatkan fungsi dan tujuan sebelumya [7].

Mengenai pengertian membaca, banyak ahli yang mengemukan pendapatnya untuk mendefenisikan membaca, hal ini tergantung darimana meninjaunya. Membaca melibatkan proses identifikasi dan proses mengingat suatu bacaan yang disajikan sebagai rangsangan untuk membangkitkan pengalaaman melalui konsep-konsep yang telah dibaca [8]. Membaca merupakan suatu proses menangkap atau memperoleh konsep-konsep yang dimaksud oleh pengarangnya, menginterpretasi, mengevaluasi dan merefleksikan atau bertindak seperti yang dimaksud dalam konsep itu. Kemampuan membaca tidak hanya mengoperasikan berbagai ketrampilan untuk memahami kata-kata dan kalimat tetapi juga kemampuan untuk menginterpretasi, mengevaluasi sehingga diperoleh pemahaman yang komprehensif.

Berdasarkan hasil observasi yang peneliti lakukan di Sekolah Dasar Negeri 54/IX Sungai Gelam, khususnya pada perpustakaan, dengan adanya program revitalisasi, ruangan perpustakaan sudah terlihat bagus, sarana dan prasana sudah cukup memadai, pemanfaatan perpustakaan sekolah sebagai sumber belajar sudah termanfaat dengan baik serta pengelolaan yang bagus dari staf perpustakaan dapat meningkatkan keinginan siswa untuk berkunjung ke perpustakaan.

Hal demikianlah yang seharusnya terjadi disetiap sekolah, karena perpustakaan sekolah adalah salah satu sumber belajar dan harus dimanfaatkan oleh seluruh warga sekolah, terutama oleh siswa. Oleh karena itu, harus dilakukan manajemen dan program yang baik terhadap perpustakaan sekolah agar keberadaannya lebih efektif. Permasalahan itulah yang membuat peneliti untuk mengetahui lebih dalam perpustakaan Sekolah Dasar Negeri 54/IX Sungai Gelam. Agar perpustakaan sekolah berperan penting sebagai laboratorium dinamika intelektual siswa maupun guru.

\section{METODE PENELITIAN}

Penelitian ini menggunakan pendekatan penelitian kualitatif yang akan menghasilkan data deskriptif dengan berusaha mengungkapkan kajian tentang revitalisasi perpustakaan sekolah. Jenis penelitian ini adalah fenomenologi. berikut:

Sumber data utama dalam penelitian kualitatif ialah kata-kata, dan tindakan,sumber data sebagai

1. Kata-kata dan Tindakan

Kata-kata dan tindakan orang-orang yang diamati atau diwawancarai merupakan sumber data utama.Sumber data utama dicatat melalui data tertulis.Dalam penelitian ini, objek yang diamati atau diwawancarai adalah staf perpustakaan, siswa dan kepala sekolah.

2. Sumber Tertulis

Sumber tertulis meliputi sumber buku, sumber dari arsip, dokumen pribadi, dan dokumen resmi yang berkaitan dengan penelitian ini. Gelam.

Subjek yang dituju adalah minat baca siswa setelah dilakukan revitalisasi di SDN 54/IX Sungai

Teknik pengumpulan data yang digunakan dalam penelitian ini adalah teknik observasi, wawancara dan dokumentasi. Alat pengumpulan data pada penelitian ini meliputi; 1) Alat perekam; 20 Kamera.

Teknik analisis data yang digunakan dalam penelitian ini yaitu peneliti menggunakan model Miles an Hubermen [10] untuk menganalisi data yang telah ada dilakukan secara interaktif dan berlangsung secara terus menerus sampai tuntas, sehingga datnya jenuh. Model ini dilakukan dengan beberapa tahapan yang diawali dengan pengumpulan data, reduksi data, penyajian data menarik kesimpulan. 
Tahap-tahap menganalisis data sebagai berikut:

1. Mengumpulkan data, yaitu semua hasil dari data kegiatan observasi dan wawancara yang dilakukan, yang disebut data mentah;

2. Mereduksi data, setelah terkumpul peneliti menyeleksi data, menyederhanakan, memfokuskan, dan mengelompokkan data yang telah diperoleh di lapangan. Setelah itu peneliti melakukan abstraksi atau membuat ringkasan data;

3. Mendisplay data, merangkai informasi dan mengecek keabsahan dari data dalam upaya mengambil kesimpulan;

4. Memverifikasi data, membuat kesimpulan, menganalisis, dan memutuskan bagaimana kebiasaan belajar siswa berprestasi;

5. Membuat laporan;

Setelah melakukan langkah-langkah tersebut, kemudian peneliti akan mendapatkan hasil penelitian, dengan mengembangkan data yang diperoleh dari instrument pemerolehan data yang telah dibuat oleh peneliti sebelumnya [11]. Dengan demikian peneliti akan mendapatkan jawaban dari rumusan masalah pada penelitian yang dilakukan oleh peneliti. Dalam penelitian kualitatif ini hanya didapatkan hasil berupa faktafakta yang diperoleh di lapangan tanpa merekayasa hasil temuan tersebut agar diperoleh data yang asli berdasarkan kenyataan yang terjadi di lapangan[12].

\section{HASIL DAN PEMBAHASAN}

Berdasarkan hasil penelitian, maka dapat dijelaskan sebagai berikut:

\section{Revitalisasi Perpustakaan Sekolah untuk Meningkatkan Minat Baca Siswa}

Hasil dari merevitalisasi perpustakaan meliputi: perpustakaan dijadikan sebagai tempat yang nyaman, perpustakaan dijadikan sebagai tempat kegiatan rutin untuk membaca dan mengisi waktu luang, staf perpustakaan bekerjasama dengan guru menjadikan perpustakaan sebagai tempat siswa mencari materi pelajaran.

a. SDN 122/IX Petaling memiliki ruangan perpustakaan tersendiri yang terpisah dari ruangan lain. Ruang yang terdapat di perpustakaan meliputi ruangan buku dan ruangan membaca. Adapun kebijakan yang diberikan sekolah agar perpustakaan dapat dimanfaatkan untuk meningkatkan minat baca siswa di SDN 122/IX Petaling adalah dengan menyediakan sarana dan prasarana yang menunjang seperti ruang dan koleksi buku yang memadai. 122/IX Petaling telah membuat tempat khusus untuk siswa agar dapat membaca secara nyaman dan didukung dengan adanya buku penunjang seperti buku pelajaran, cerita ataupun buku lainya yang berhubungan dengan pendidikan. Dengan adanya sarana dan prasarana yang tersebut, kegiatan membaca diperpustakaan menjadi lebih baik dan menyenangkan,dengan begitu siswa akan lebih tertarik untuk berkunjung dan membaca di perpustakaan

b. Setelah sarana dan prasarana penunjang yang berada di perpustakaan terpenuhi, sekolah membuat kebijakan yaitu dengan membuat jadwal kunjungan bagi masing-masing kelas. Pembuatan jadwal dilakukan dengan tujuan agar setiap siswa dapat mengunjungi perpustakaan secara berkala. Dengan adanya jadwal diharapkan semua siswa dapat terbiasa mengisi waktu ketika berada disekolah dengan membaca diperpustakaan. Pembuatan jadwal kunjungan wajib bagi siswa ke perpustakaan dilakukan agar siswa yang kurang memiliki minat untuk membaca akan perlahan terbiasa untuk membaca dan dengan jadwal tersebut pihak sekolah dapat turut serta meningkatkan minat baca siswa SDN 122/IX Petaling.

Perpustakaan sebagai tempat siswa mecari materi pelajaran, kegiatan ini selain dapat membantu siswa menambah pemahaman dengan membiasakan diri berkunjung ke perpustakaan juga dapat membantu siswa untuk saling berinteraksi dengan sesama teman. Kegiatan ini dapat menjadi sarana agar siswa dapat menjalankan tugasnya sebagai makhluk sosial.

\section{KESIMPULAN}

Berdasarkan penelitian yang telah dilakukan, dapat diambil kesimpulan bahwa, untuk meningkatkan minat baca siswa di SDN 122/IX Petaling diperlukan langkah-langkah yang nyata, dalam hal ini khususnya sikap pimpinan dan staf perpustakaan yang lebih peduli dengan perpustakaan. Minat baca siswa SDN 122/IX Petaling sudah semakin meningkat dari sebelumnya. Dengan adanya program revitalisasi dan kerjasama yang baik antar warga sekolah. 


\section{UCAPAN TERIMA KASIH}

Terimakaish kepada seluruh responden yang telah bersedia, sehingga penelitian ini dapat saya selesaikan. Serta semua elemen yang telah ikut berpartisipasi, saya ucapkan terimakasih

\section{REFERENSI}

[1] Sutarno NS. Perpustakaan dan Masyarakat, CV. Sagung Seto, Jakarta, 2006

[2] A. Asrial, S. Syahrial, D. A. Kurniawan, R. Septiasari, "Hubungan Kompetensi Pedagogik Dengan Kompetensi IPA Mahasiswa Pendidikan Guru Sekolah Dasar," Pedagogia: Jurnal Penididikan, vol. 8, no. 2, pp. 149-157, 2019

[3] Bafadah. Pengelolaan Perpustakaan Sekolah. Universitas Terbuka, 2015

[4] S. Syahrial, A. Asrial, D. A. Kurniawan, P. Nugroho, R. Septiasari, R. A. Pratama, and R. Perdana, "Increased Behavior of Students' Attitudes to Cultural Values Using the Inquiry Learning Model Assisted Ethno constructivism," Journal of Educational Science and Technology (EST), vol. 5, no. 2, pp. 166-175, 2019

[5] A. Asrial, S. Syahrial, D. A. Kurniawan, M. Subandiyo, and N. Amalina, "Exploring Obstacles in Leanguage Learning Among Prospective Primay School Teacher," International Journal of Evaluation and Research in Education, vol. 8, no. 2, pp. 249-254, 2019

[6] D. A. Kurniawan, A. Astalini, D. Darmaji, R. Melsayanti, "Student's Attitude Towards Natural Science," International Journal of Evaluation and Research in Education (IJERE), vol. 8, no. 3, pp. 463-468, 2019

[7] Darmaji, D. A Kurniawan, Astalini, A. Lumbantoruan, and S. C. Samosir. "Mobile Learning In Higher Education For The Industrial Evolutioin 4.0: Perception and Response of Physics Practicum," International Journal of Interactive Mobile (IJIM), vol. 13, no. 9, pp. 4-20, 2019

[8] A. Asrial, S. Syahrial, D. A. Kurniawan, and N. Amalina, "Analisis Hubungan Kompetensi Bahasa Indonesia Terhadap Kompetensi Pedagogik Mahasiswa Pendidikan Guru Sekolah Dasar," Premiere Educandum: Jurnal Pendidikan Dasar dan Pembelajaran, vol. 9, no. 1, pp. 1-8, 2019.

[9] D. Darmaji, D. A. Kurniawan, A. Astalini, and N. R. Nasih, "Persepsi Mahasiswa pada Penuntun Praktikum Fisika Dasar II Berbasis Mobile Learning," Jurnal Pendidikan: Teori, Penelitian, dan Pengembangan, vol. 4, no. 4, pp. 516-523, 2019.

[10] Sugiyono, Memahami Penelitian Kualitatif. Bandung : Jakarta, 2016

[11] D. Darmaji, A. Astalini, D. A. Kurniawan, and R. Perdana, "A study relationship attitude toward physics, motivation, and character discipline students senior high school, in Indonesia," International Journal of Learning and Teaching, vol. 11, no. 3, pp. 99-109, 2019.

[12] M. Maison, D. Darmaji, A. Astalini, D. A. Kurniawan, and P. Indrawati, "Science process skills and motivation," Humanities \& Social Sciences Reviews (HSSR), vol. 7, no. 5, pp. 48-56, 2019 